\title{
Ameliorative Potential of Biocharcoal on Sodium Azide Toxicity in African Yam Bean (Sphenostylis stenocarpa Hochst. Ex. A. Rich) Harms.
}

\section{*OSHOMOH, EO; ILODIGWE, CC}

\author{
Department of Science Laboratory Technology, Faculty of Life Sciences, University of Benin, Benin, Nigeria
} *Corresponding Author Email emmanuel.oshomoh@uniben.edu; +2348055452141

\begin{abstract}
S: The study focused primarily on evaluating the ameliorative potential of biocharcoal on sodium azide toxicity (35 ppm) in African yam bean (Sphenostylis stenocarpa Hochst. Ex. A. Rich) Harms. A field experiment was conducted using river sand and mixtures of biocharcoal from Pentaclethra macrophylla, represented by 0 (100\% river sand, control), 25, 50, 75 and $100 \%$ biocharcoal added to ameliorate the toxic effects of sodium azide on African yam bean. Morphological parameters measured include germination percentage, number of leaves and secondary roots, percentage seedling emergence, shoot height, number of branches and number of leaves were recorded. The effect of biocharcoal on the toxicity of sodium azide to soil $\mathrm{pH}$, conductivity, nitrogen, phosphorus, potassium contents and microbial community were also recorded. The growth of African yam bean was significantly improved by the application of the biocharcoal as higher plant height, number of leaves, percentage seedling emergence and number of branches were observed when compared with control. Soil conductivity, potassium and phosphorus were significantly higher in the treatments with biocharcoal. No positive effect on soil nitrogen content was observed. Biocharcoal addition adversely affected soil microbial community. Biocharcoal proved to have ameliorative potential however more work is needed to understand the mechanism by which it operates.
\end{abstract}

\section{DOI: https://dx.doi.org/10.4314/jasem.v22i5.11}

Copyright: Copyright (C) 2018 Oshomoh and Ilodigwe. This is an open access article distributed under the Creative Commons Attribution License (CCL), which permits unrestricted use, distribution, and reproduction in any medium, provided the original work is properly cited.

Dates: Received: 11 March 2018; Revised: 09 April: 2018; Accepted: 25 April 2018

Keywords: Mutants, sodium azide, biochacoal, microbial community

With increase in world population of humans, food security and its sustainability become a global concern. Chemical mutagens, one of the three types of mutagens, has been shown to create mutant of desirable quality for example sodium azide $\left(\mathrm{NaN}_{3}\right)$ on cowpea, $\mathrm{NaN}_{3}$ on rice, $\mathrm{NaN}_{3}$ on maize. Irrespective of these positive results obtained from chemical mutagenesis in plant and adverse effect of these mutagen from crop have also been reported. This therefore forms the basis of this research. Irrespective of the aforementioned advantages, mutation breeding with the use of chemical mutagens could be detrimental to the health and yield of plants (Khan and Al-Quarainy, 2009) and this should be taken seriously because mutagens can be found in the environment as pesticides, food additives, industrial chemicals and industrial effluents, hence this research to investigate the effectiveness of Bio-charcoal in ameliorating the possible negative effects of the mutagen, Sodium azide, on the test plant African yam bean (Sphenostylis stenocarpa (Hochst. Ex. A. Rich) Harms).

Biocharcoal is a material produced by the thermochemical pyrolysis of biomass material. It can be used in soil amendment for improving soil properties/quality and enhancing significant increase in crop yields thus promoting plant productivity (Mensah and Ekeke, 2016). The addition of biocharcoal on the soil can improve soil properties and have other environmental benefit (Thi et al., 2013). Charcoal improves nutrient retention capacity and increase soil fertility (Glaser et al., 2002). The improved nutrient retention may also lead to less nutrient leaching. Applying charcoal to the soil can improve water holding capacity (Chan et al., 2007). Charcoal usually increases soil $\mathrm{pH}$ because it contains some ash which can act as liming agent as well as phosphorus (P), potassium (K) fertilizer (Thi et al., 2013). African yam bean (Sphenostylis stenocarpa Hochst. Ex. A. Rich) is an herbaceous leguminous plant occurring throughout tropical Africa. African yam bean is an underutilized species with great genetic and economic potential, African yam bean is one of many indigenous food crops of Africa which have tendency to ameliorate nutritional food insecurities but it is neglected due to poor awareness and limited research about the taxonomy, agronomy, genetics, medicinal value and productive potentials of the crops. The subsistence production of the crop may have been occasioned by the poor acceptability as a valuable crop 
among middle aged farmers in Africa (Adewale et al., 2012) and its low consumption rate is mainly due to its long cooking time. The generic name Sphenostylis arose from a greek word "Sphen" meaning wedge shape. Therefore, the genus Sphenostylis comprises a group of leguminous species with dorsiventrally cuncate style with flattened stigmatic tip. Former grouping within the two genera was because they were found to be closely related to them hence most species in the genus Sphenostylis initially bear Dolchius and Vigna synonyms (Adewale et al., 2012). African yam bean belongs to the order fabales and the family fabaceae.

The objective of paper is to investigate the ameliorative potentials of biocharcoal on sodium azide toxicity (35ppm) in African yam bean (Sphenostylis stenocarpa Hochst. Ex. A. Rich) Harms

\section{MATERIALS AND METHODS}

Experimental Site: This experiment was carried out in the Botanical Garden of the Department of Plant Biology and Biotechnology, Faculty of Life Sciences, University of Benin. The seeds of African yam bean (Umuidike local) were purchased from a local market in Umuidike, Abia State. The sodium azide chemical used for this experiment was purchased from Mosdelic Chemical Store, University of Benin, Benin City. River sand utilized for this experiment was obtained from a construction site within the University of Benin's premises. The charcoal utilized was purchased from a saw mill in Ovbiogie, Ovia North East Local Government, Edo State.

The experiment consisted of five sets of treatments each having six replicates. The first set contained 100 $\%$ river sand to $0 \%$ biocharcoal. The second set contained $75 \%$ river sand to $25 \%$ biocharcoal. The third contained equal proportion of river sand and biocharcoal. The fourth had a combination of $25 \%$ sand to $75 \%$ biocharcoal while the last set was made up of $100 \%$ biocharcoal. Total weight of soil and biocharcoal mixture contained $1500 \mathrm{~g}$ in each nursery bag. Each bag was irrigated with $35 \mathrm{mg} / \mathrm{l} \mathrm{NaN}_{3}$ regularly. The charcoal used was made from the wood of Pentaclethra macrophylla commonly called Okpagha in Edo state and ûkpagā in the Eastern part of Nigeria. Physiological and morphological parameters like the seedling emergence percentage, number of leaves and secondary roots were recorded in the laboratory and plant height, number of leaves and number of branches were recorded in the field experiment. Soil used for the experiment was subjected to chemical analysis and microbial analysis at the tail end of the experiment. The result obtained from the experiment was arranged and then subjected to ANOVA using the SPSS version 16.0 software (Ogbeibu, 2005).

\section{RESULTS AND DISCUSSION}

The result of the effect of charcoal on the percentage seedling emergence of African yam bean subjected to sodium azide pollution is presented in table 1 . The addition of biocharcoal had no positive effect at the first two weeks but significantly higher percentage seedling emergence was recorded at the third week after planting in the treatments with biocharcoal amendment (Table 1). The chemistry of azide's reaction with biocharcoal or carbon compounds is still a current interest of researchers (Halbig et al., 2015) however there is no documentation to the best of my knowledge on the possible effect biocharcoal can have on mutagenicity. So, the mechanism responsible for the result seen in table 1 of this study is farfetched. However, biocharcoal has been proven to have ameliorative potentials as it can adsorb toxic compounds (Brendova et al., 2015; Cui et al., 2011) and this supports the results of this study. Test subjects in the treatment with biocharcoal amendment recorded higher plant height than those of the control treatment and this was observed from the first week to the sixth week after treatment. No growth was recorded in the control treatment. The results seen in table 2 of this study is in agreement with that of Pluchon et al. (2014) who reported that charcoal has ameliorative properties and can act as an adsorbent for negative compounds. The lack of growth observed in the control treatment is in agreement with Akhtar (2014) than mutagens can have adverse effects on shoot height. The result in table 2 of this study is also in agreement with the report by Mensah and Obadoni (2007) who reported a concentration dependent adverse effect of sodium azide on the shoot height of Arachis hypogaea L. The exact mechanism by which biocharcoal boosted the shoot growth of African yam bean subjected to sodium azide pollution is yet to be understood, however besides ameliorative abilities biocharcoal has also been reported to be a stimulant to plant growth (Roy et $a l ., 2012$ ). The result of the effect of biocharcoal on the number of leaves of Sphenostylis stenocarpa subjected to sodium azide pollution is presented in this table 3. Test plants in the treatment with the biocharcoal amendment had more number of leaves than the control treatment, in which no leaf growth was recorded. In table 3 , it is seen that no leaf was produced in the control treatment as sodium azide at $30 \mathrm{mg} / \mathrm{l}$ concentration significantly inhibited the growth of African yam bean. This is supported by the result of Gnanamurthy et al. (2012) who reported the adverse effect of sodium azide on the leaf growth of Zea mays. The boost in leaf production by biocharcoal is supported also by Herath et al. (2015); DiazMuegue et al. (2016) and Mensah and Ekeke (2016) 
who all stated that biocharcoal can sustain the growth of plants under duress. The result of the effect of biocharcoal on the number of branches of Sphenostylis stenocarpa subjected to sodium azide pollution is presented in table 4 . No branches were observed in the control treatment as no growth was observed there but treatments with the biocharcoal amendments recorded significantly higher number of branches.

Table 1: Effects of biocharcoal on the percentage seedling emergence of Sphenostylis stenocarpa grown under sodium azide pollution.

\begin{tabular}{|c|c|c|c|}
\hline \multirow[t]{2}{*}{ TREATMENTS } & \multicolumn{3}{|c|}{ TIMES (WEEK) } \\
\hline & 1 & 2 & 3 \\
\hline $25 \%$ charcoal $+75 \%$ soil & $15.00 \pm 2.89^{\mathrm{a}}$ & $16.67 \pm 6.67^{\mathrm{a}}$ & $23.33 \pm 1.67^{\mathrm{b}}$ \\
\hline $75 \%$ charcoal $+25 \%$ soil & $16.67 \pm 8.82^{\mathrm{a}}$ & $16.67 \pm 8.82^{\mathrm{a}}$ & $25.83 \pm 8.70^{\mathrm{b}}$ \\
\hline $100 \%$ charcoal & $3.33 \pm 3.33^{\mathrm{a}}$ & $11.67 \pm 1.67^{\mathrm{a}}$ & $15.00 \pm 8.70^{\mathrm{b}}$ \\
\hline P-value & 0.169 & 0.402 & 0.022 \\
\hline
\end{tabular}

Table 2: Effects of biocharcoal on the shoot height of Sphenostylis stenocarpa grown on sodium azide polluted soil.

\begin{tabular}{|c|c|c|c|c|}
\hline \multirow[t]{2}{*}{ TREATMENTS } & \multicolumn{4}{|c|}{ TIMES (WEEK) (cm) } \\
\hline & 3 & 4 & 5 & 6 \\
\hline $100 \%$ soil (control) & $0.00 \pm 00^{\mathrm{a}}$ & $0.00 \pm 0.00^{\mathrm{a}}$ & $0.00 \pm 0.00^{\mathrm{a}}$ & $0.00 \pm 0.00^{\mathrm{a}}$ \\
\hline $25 \%$ charcoal $+75 \%$ soil & $9.75 \pm 0.90^{\mathrm{b}}$ & $10.22 \pm 1.48^{\mathrm{b}}$ & $9.75 \pm 4.88^{\mathrm{b}}$ & $5.67 \pm 5.67^{\mathrm{a}, \mathrm{b}}$ \\
\hline $50 \%$ charcoal $+50 \%$ soil & $10.96 \pm 3.71^{b}$ & $9.31 \pm 0.78^{b}$ & $12.26 \pm 0.75^{\mathrm{b}}$ & $13.50 \pm 0.58^{\mathrm{b}, \mathrm{c}}$ \\
\hline $75 \%$ charcoal $+25 \%$ soil & $10.34 \pm 0.77^{\mathrm{b}}$ & $11.72 \pm 1.64^{\mathrm{b}}$ & $15.27 \pm 1.67^{\mathrm{b}}$ & $15.04 \pm 0.81^{\mathrm{c}}$ \\
\hline $100 \%$ charcoal & $9.24 \pm 1.05^{\mathrm{b}}$ & $11.64 \pm 0.95^{\mathrm{b}}$ & $13.13 \pm 0.91^{\mathrm{b}}$ & $16.02 \pm 1.12^{\mathrm{c}}$ \\
\hline $\mathrm{P}$-value & 0.000 & 0.000 & 0.008 & 0.006 \\
\hline Significance (at $\mathrm{P} \leq 0.05$ ) & S & $\mathrm{S}$ & S & $\mathrm{S}$ \\
\hline
\end{tabular}

$S=$ significant $;$ NS $=$ not significant $;$ Level of significance $=0.05 ;$ Duncan multiple range test $($ mean comparison) $=$ mean \pm standard error

Table 3: Effects of biocharcoal on number of leaves of Sphenostylis stenocarpa grown on sodium azide polluted soil.

\begin{tabular}{lllll}
\hline \multicolumn{1}{c}{ TREATMENTS } & \multicolumn{3}{c}{ TIMES (WEEK) } \\
& 3 & 4 & 5 & 6 \\
\hline $100 \%$ soil (control) & $0.00 \pm 0.00^{\mathrm{a}}$ & $0.00 \pm 0.00^{\mathrm{a}}$ & $0.00 \pm 0.00^{\mathrm{a}}$ & $0.00 \pm 0.00^{\mathrm{a}}$ \\
$25 \%$ charcoal + 75\% soil & $6.00 \pm 0.50^{\mathrm{b}}$ & $2.67 \pm 2.67^{\mathrm{a}}$ & $4.00 \pm 2.00^{\mathrm{b}}$ & $3.00 \pm 3.00^{\mathrm{ab}}$ \\
$50 \%$ charcoal + 50\% soil & $3.50 \pm 0.87^{\mathrm{b}}$ & $8.78 \pm 1.77^{\mathrm{b}}$ & $11.67 \pm 1.20^{\mathrm{cd}}$ & $8.83 \pm 0.17^{\mathrm{bc}}$ \\
$75 \%$ charcoal + 25\% soil & $4.92 \pm 0.65^{\mathrm{b}}$ & $8.36 \pm 1.87^{\mathrm{b}}$ & $7.81 \pm 0.81^{\mathrm{bc}}$ & $10.12 \pm 1.77^{\mathrm{c}}$ \\
$100 \%$ charcoal & $5.50 \pm 1.32^{\mathrm{b}}$ & $11.08 \pm 0.87^{\mathrm{b}}$ & $12.94 \pm 1.38^{\mathrm{d}}$ & $13.50 \pm 3.28^{\mathrm{c}}$ \\
P-value & 0.002 & 0.012 & 0.015 & 0.002 \\
Significance (at P $\leq 0.05)$ & $\mathrm{S}$ & $\mathrm{S}$ & $\mathrm{S}$ & $\mathrm{S}$ \\
\hline
\end{tabular}

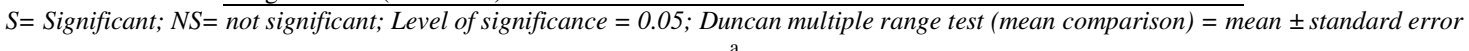

Table 4: Effects of biocharcoal on number of branches of Sphenostylis stenocarpa grown on sodium azide polluted soil.

\begin{tabular}{lllll}
\hline TREATMENTS & \multicolumn{3}{c}{ TIMES (WEEK) } \\
& 3 & 4 & 5 & 6 \\
\hline $100 \%$ soil (control) & $0.00 \pm 0.00^{\mathrm{a}}$ & $0.00 \pm 0.00^{\mathrm{a}}$ & $0.00 \pm 0.00^{\mathrm{a}}$ & $0.00 \pm 0.00^{\mathrm{a}}$ \\
$25 \%$ charcoal + 75 \% soil & $2.33 \pm 0.33^{\mathrm{b}}$ & $4.00 \pm 00^{\mathrm{c}}$ & $1.33 \pm 0.67^{\mathrm{a}, \mathrm{b}}$ & $1.00 \pm 1.00^{\mathrm{a}, \mathrm{b}}$ \\
$50 \%$ charcoal + 50\% soil & $1.33 \pm 0.33^{\mathrm{b}}$ & $0.00 \pm 0.00^{\mathrm{a}}$ & $4.00 \pm 0.58^{\mathrm{b}}$ & $3.00 \pm 0.00^{\mathrm{b}, \mathrm{c}}$ \\
$75 \%$ charcoal + 25\% soil & $1.67 \pm 0.33^{\mathrm{b}}$ & $0.75 \pm 0.48^{\mathrm{a}}$ & $3.00 \pm 0.00^{\mathrm{b}, \mathrm{c}}$ & $3.67 \pm 0.67^{\mathrm{c}}$ \\
$100 \%$ charcoal & $2.00 \pm 0.58^{\mathrm{b}}$ & $2.50 \pm 0.29^{\mathrm{b}}$ & $4.33 \pm 0.88^{\mathrm{c}}$ & $4.67 \pm 1.20^{\mathrm{c}}$ \\
P-value & 0.000 & 0.012 & 0.000 & 0.003 \\
Significance (at P $\leq 0.05)$ & $\mathrm{S}$ & $\mathrm{S}$ & $\mathrm{S}$ & $\mathrm{S}$ \\
\hline
\end{tabular}

$S=$ Significant $; \mathrm{NS}=$ not significant $;$ Level of significance $=0.05 ;$ Duncan multiple range test $($ mean comparison) $=$ mean \pm standard error

From table 4 it shows that growth didn't occur in the control treatment and this is supported by the result obtained by Nakweti et al. (2015) who reported that sodium azide can have adverse effect on branch formation in plants. The boost in branch production by biocharcoal on African yam bean subjected to sodium azide toxicity as shown by the result on table 4 in this study is supported by Herath et al. (2015), DiazMuegue et al. (2016) and Mensah and Ekeke (2016) who all confirmed that biocharcoal can soak up toxic substances and may possess ameliorative properties.
The result of the effect of charcoal on the $\mathrm{pH}$ of the soil polluted with sodium azide is presented in figure 1. The soil $\mathrm{pH}$ did not follow any particular trend however the highest $\mathrm{pH}$ was obtained in the treatment with $50 \%$ biocharcoal while the lowest $\mathrm{pH}$ value was recorded in the treatment with $25 \%$ biocharcoal. Gruszka et al. (2012) reported that sodium azide toxicity is affected by soil $\mathrm{pH}$. This makes it important to know the effect of biocharcoal on soil $\mathrm{pH}$. 


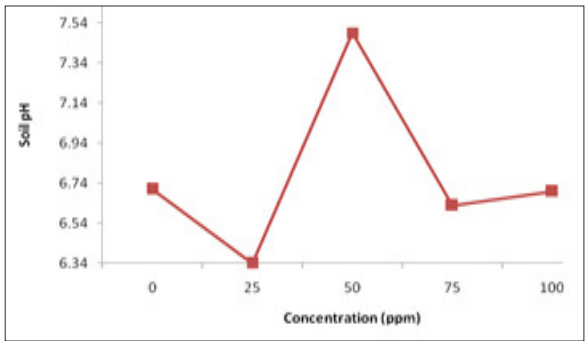

Fig 1: Effect of biocharcoal on $\mathrm{pH}$ of soil polluted with sodium azide.

The result of this study as seen in figure 1 agrees with the report by Zhang et al. (2016) who reported that biocharcoal addition increased soil $\mathrm{pH}$. However, the increase reported in this study was only observed at 25 $\%$ Biocharcoal treatment. No peculiar trend was observed when taking all treatments into perspective. It is important to note that the high $\mathrm{pH}$ in the control treatment is in agreement with the report by Chefetz et al. (2006) that sodium azide can elevate soil $\mathrm{pH}$. The effect of biocharcoal amendment on soil conductivity is presented in figure 2 . The result of the conductivity followed an interesting trend. The results show that as the proportion of charcoal used increases so did the conductivity of the soil.

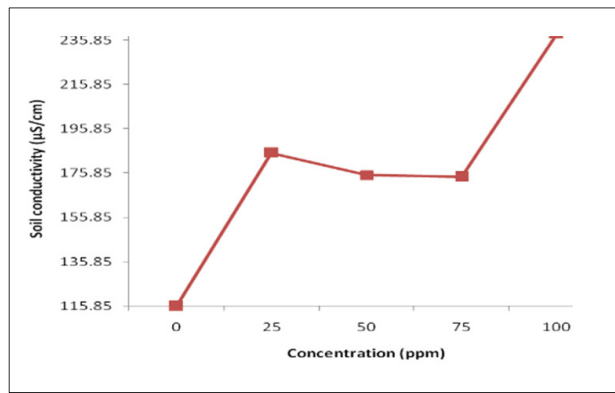

Fig 2: Effect of biocharcoal on conductivity of soil polluted with sodium azide.

The result in figure 2 of this study is in agreement with the report by Nabavinia et al. (2015) and Zhang et al. (2016) who reported that biocharcoal addition led to elevated soil conductivity. Hence, in this study better growth performance was recorded in soil with elevated conductivity. The effect of biocharcoal amendment on the nitrogen content of soil polluted with sodium azide is shown in figure 3 . Treatments with $25,50,75$ and $100 \%$ had lower soil nitrogen content compared to the control treatment which had the highest nitrogen content. In figure 3 has shown the effect of biocharcoal on soil nitrogen content of a soil polluted with sodium azide however it is relevant to note that biocharcoal additions has been reported to increase soil nitrogen content (Nigussie and Kissi, 2011).

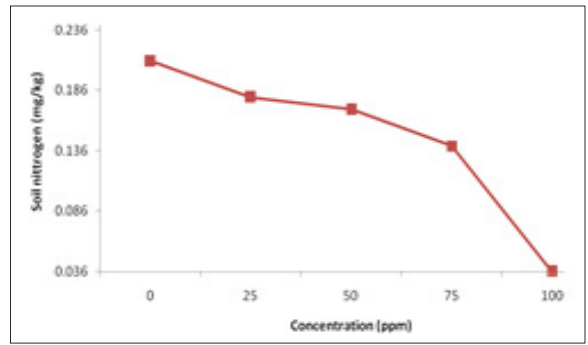

Fig 3: Effect of biocharcoal on Nitrogen content of soil polluted with sodium azide.

Thi et al. (2013) says biocharcoal can't replace fertilizer as nitrogen is highly needed for plant growth. Mitchual et al. (2014) also reported that biocharcoal's effect on nitrogen varies with the source of the wood used to prepare it.

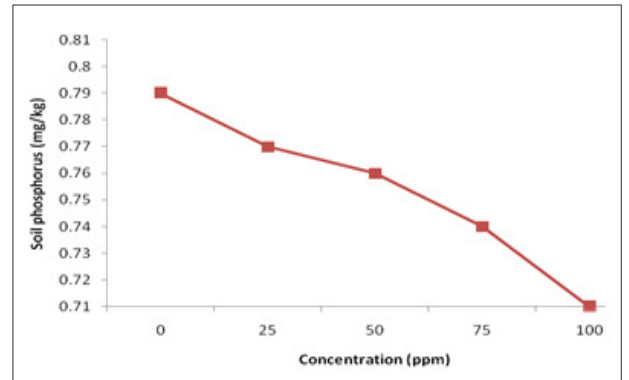

Fig 4: Effect of biocharcoal on phosphorus content of soil polluted with sodium azide.

The effect of biocharcoal on the soil phosphorus content of soil polluted with sodium azide is presented in the folowing figure 4 . The soil phosphorus content was shown to reduce with increase in the proportion of biocharcoal utilized.

The result gotten from figure 4 of this study is not in agreement with the reports of Lehmann et al. (2011); Nabavinia et al. (2015) and Thi et al. (2013), who reported that biocharcoal addition can increase the phosphorus content of the soil as the phosphorus content didn't increase when soil was amended with biocharcoal. Biocharcoal has been referred to as a potassium fertilizer by Thi et al. (2013). Result of this effect of biocharcoal amendment on potassium content of soil polluted with sodium azide is presented in table 5. The soil potassium content was shown to increase in direct proportion to the percentage biocharcoal applied. The control had the least potassium soil content while the treatment with $100 \%$ biocharcoal had the highest soil potassium content. This agrees with the report from figure 5 of this study as potassium was observed to increase with increase in biocharcoal proportion used. Chefetz et al. (2006) reported sodium azide to be biocidal on bacterial and fungal population. 


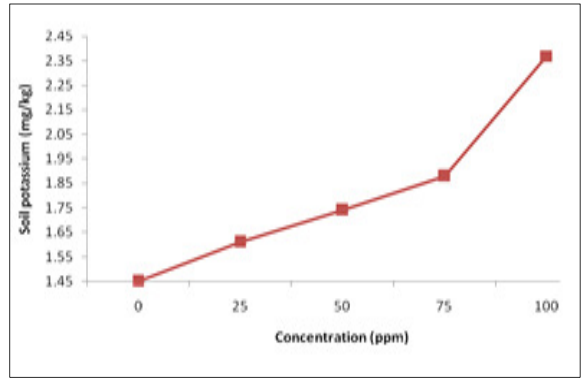

Fig 5: Effect of biocharcoal on potassium content of soil polluted with sodium azide.

Sreeju et al. (2011) reported the contrary. More work is needed to understand the reason for the differences in reports. Adeniyi (2010) supported that biocharcoal could have an effect on microbial community. Bacteria count of sodium azide polluted soil amended with biocharcoal is presented in figure 6 . Treatment with $25 \%$ and $50 \%$ Biocharcoal significantly boosted bacteria colony count but the value was shown to reduce as the proportion of biocharcoal used reduced. The control treatment had the second lowest bacteria colony count. Lehmann et al. (2011) reported that biocharcoal can increase microbial biomass and the result from figure 6 agree with this report. The boost in bacteria colony count as shown by the result from figure 6 of this study is also in agreement with the report by Meynet et al. (2002). The decline in bacteria colony count recorded in the ultimate and penultimate treatments with biocharcoal can't be fully elucidated as there is no visible literature on the effect of the interaction of biocharcoal and sodium azide on bacteria colony count.

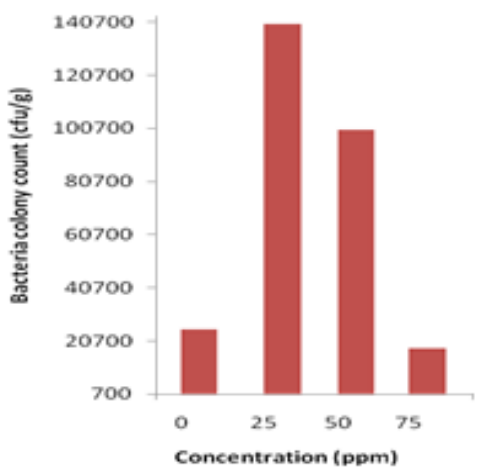

Fig 6: Effect of biocharcoal on bacteria colony count of soil polluted with sodium azide.

Results of the effect of biocharcoal amendment on specific bacteria of sodium azide polluted soil is presented in table 5. Biocharcoal amendment affected soil bacteria composition as the control treatment had more of the specific isolates screened than the treatments with the biocharcoal amendment. The result also showed that $25 \%$ biocharcoal amendment had equal effect as the control treatment making it less of a biocide.

Table 5: Effect of biocharcoal on the specific bacteria presence in the screening of soil treated with sodium azide

\begin{tabular}{ll}
\hline S amples (30 ppm) & \multicolumn{1}{c}{ Isolates } \\
\hline $0 \%$ & Staphlococcus aur eus, Bacillus substil is, E. coli, Klebsiella sp., \\
$25 \%$ & Staphlococcus aur eus, Bacillus substil is, E. coli, Klebsiella sp. \\
$50 \%$ & Staphlococcus aur ous, E. coli, Klebsiella sp. \\
$75 \%$ & Staphlococcus aur eus, Bacillus substil is \\
$100 \%$ & Staphlvlococcus aur eus \\
\hline
\end{tabular}

Table 6: Effect of biocharcoal on the specific fungi presence screening of soil treated with sodium azide

\begin{tabular}{ll}
\hline Samples (30 Ppm) & Isolates \\
\hline $0 \%$ & Aspergillus flavus, Trichoderma harzianum, Mucor mucedo, Fusarium solani, Aspergillus niger \\
$25 \%$ & Trichoderma harzianum, Aspergillus flavus, Mucor mucedo, Aspergillus niger \\
$50 \%$ & Aspergillus flavus, Aspergillus niger \\
$75 \%$ & Aspergillus niger, Mucor mucedo \\
$100 \%$ & Mucor mucedo, Aspergillus niger \\
\hline
\end{tabular}

The result of the effect of charcoal application on the microbial fungi colony count of soil treated with sodium azide is presented in figure 7 . The control treatment had the highest fungi colony count while the treatment with $100 \%$ biocharcoal amendment had the least fungi colony count.

Sodium azide was reported to negatively affect fungal population by Kumi et al. (2013) and the result from figure 7 of this study disagrees with this report as the control treatment, the treatment with $30 \mathrm{ppm} \mathrm{NaN}_{3}$ had the highest fungal colony count. The result from figure 7 is also in agreement with the report of Gao et al. (2016) who states that biocharcoal can have varying effect on fungal population and can also tilt the odds in favor of the bacteria population. The result of the effect of charcoal on specific fungi presence in the screening of soil polluted with sodium azide is presented in table 6 . 


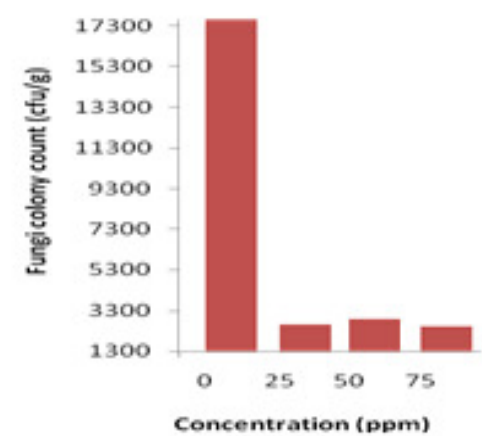

Fig 7: Effect of biocharcoal on fungi colony count of soil polluted with sodium azide.

The presence of the specific fungi isolates dwindled as the proportion of biocharcoal used increased however there was no difference in the presence of the specific fungi isolates in $25 \%$ biocharcoal treatment and the control treatment. From table 5 and 6 , it can be seen that Biocharcoal at proportions above $25 \%$ adversely affected the presence of the bacteria and fungi screened. This change, the alteration as it is in agreement with the report by Adeniyi (2010); Lehmann et al. (2011) and Gao et al. (2016) who reported that biocharcoal can alter microbial community structure. The result from table 5 and 6 differs from report by Sreeju et al. (2011) and Meynet et al. (2002) who stated that biocharcoal had no effect on soil fungi as the result showed a decline in fungi species presence with elevation in proportion of charcoal used.

Conclusion: Sodium azide may be beneficial for the production of mutant plants with desirable traits but it is not without adverse effects and not until this negative effect is controlled, the advantages of chemical mutagenesis by sodium azide will be dampened by its adverse effect. Biocharcoal proved to be a biomaterial with ameliorative potential, able to mitigate the adverse effects of sodium azide however this can't be conclusive until its mechanism of action is understood.

\section{REFERENCES}

Adeniyi, AS (2010). Effects of slash and burning on soil microbial diversity and abundance in the tropical rainforest ecosystem, Ondo State, Nigeria. Afr. J. Pl. Sci. 4: 322-329.

Adewale, BD; Dumet, DJ; Vroh-Bi, I; Kehinde, OB; Ojo, DK; Adegbite, AE; Franco, J (2012). Morphological diversity analysis of African yam bean and prospects for utilization in germplasm conservation and breeding. Gen. Res. Cr. Evol. 59: 927-936.

Akhtar, N (2014). Effect of physical and chemical behavior of tomato (Lycopersicon esculentum L.) cv. "Rio grande" under heat stress conditions. Schol. J. Agr. Sci. 4: 350-355.

Brendova, K; Thistos, P; Szakova, J (2015). Biochar immobilizes cadmium and zinc and improves phyto extraction potential of Willow plants on extremely contaminated soil. Pl. S. Environ. 61: 303-308.

Chan, KY; Zwieten, LV; Meszaros, I; Downie, A; Joseph, S (2007). Agronomic values of greenwaste biochar as a soil amendment. Austr. J. S. Res. 45: 629-634

Chefetz, B; Stinler, K; Scechter, M; Drori, Y (2006). Interactions of sodium azide with triazine herbicides: effect of sorption to soils. Chemosphere 65: 352-357.

Cui, L; Li, L; Zhang, A; Pan, G; Bao, D; Chang, A (2011). Biochar amendment greatly reduces rice Cd uptake in a contaminated paddy soil: a twoyear field experiment. BioRes. 6: 2605-2618.

Diaz-Muegue, L; Pino, N; Penuela, G (2016). Biochar from oil palm waste as an amendment for the remediation of soil disturbed by open-cast coal mining. Glob. Res. J. Eng. Techno. Innov. 5: 017022.

Gao, X; Cheng, HY; Valle, ID; Liu, S; Masiello, C; Silberg, JJ (2016). Charcoal disrupts soil microbial communication through a combination of signal sorption and hydrolysis. Amer. Chem. Soc. Ome. 1: 226-233.

Glaser, B; Lehmann, J; Zech, W (2002). Ameliorating physical and chemical properties of highly weathered soils in the tropics with charcoal. $A$ Rev. Biol. Fert. Soi. 35: 219-230.

Gnanamurthy, S; Dhanavel, D; Girija, M; Pavadai, P; Bharathi, $T$ (2012). Effect of chemical mutagenesis on quantitative traits of maize (Zeamays L.). Inter. J. Res. Bot. 2: 34-36.

Gruzka, D; Szarejko, I; Maluszynski, M (2012). Sodium azide as a mutagen. In: Q.Y. Shu, B. P. Foster and H. Nakagawa. Plant Mutation Breeding and Biotechnology. The inter. ato. Age. Vienna, Austria. Pp159-166. 
Halbig, CE; Rietsch, P; Eigler, S (2015). Towards the synthesis of graphene azide from graphene oxide. Mol. 20: 21050-21057.

Herath, I; Kumarathilaka, P; Navaratne, A; Rajakaruna, N; Vithanage, M (2015). Immobilization and phytotoxicity reduction of heavy metals in serpentine soil using biochar. $J$. Soi. Sedim. 15: 126-138.

Khan, S; and Al-Qurainy, F (2009). Mutagenic effect of sodium azide on seed germination of Eruca sativa (L). Austr. J. Bas. Appl. Sci. 3: 3081-3087.

Kumi, AS; Khan, V; Ankumah, RO (2013). Assessing the effects of solarization and sodium azide amendments on selected soil parameters, enzyme activities and mircobial population. J. Environ. Prot. 4: 772-778.

Lehmann, J; Rillig, MC; Thies, J; Masiello, CA; Hockaday, WC; Crowley, D (2011). Biochar effects on soil biota - a review. Soi. Biol. Biochem. 43: 1812-1836.

Mensah, IS; Ekeke, C (2016). Albizia zygia charcoal on the growth and performance of maize (Zea mays L.). Eur. J. Phy. Agric. Sci. 4: 1-9.

Mensah, JK; Obadoni, B (2007). Effects of sodium azide on yield parameters of groundnut (Arachis hypogaea L.). Afr. J. Biotechnol. 6: 668-671.

Meynet, P; Hale, SE; Davenport, RJ; Cornelissen, G; Breedveld, GD; Werner, D (2002). Effect of activated carbon amendment on bacteria community structure and functions in a $\mathrm{PAH}$ impacted urban soil. Environ. Sci. Technol. 46: 5057-5066.

Mitchual, SJ; Mensah, KF; Darkwa, NA (2014). Evaluation of fuel properties of six tropical hardwood of timber species for briquettes. J. Sust. Bioen. Sys.4:1-9.
Nabavinia, F; Emani, H; Asteraee, A; Lakzian, A (2015). Effect of tannery wastes and biochar on soil chemical and physicochemical properties and growth traits of radish. Inst. Agrophy. 29: 333339.

Nakweti, RK; Franche, C; Ndiku, SL (2015). Effects of Sodium Azide (NaN3) on Seeds Germination, Plantlets Growth and In vitro Antimalarial Activities of Phyllanthus odontadenius Müll. Arg. Amer. J. Exp. Agr. 5 (3): 226-238.

Nigussie, A; Kissi, E (2011). Impact of biomass burning on selected physicochemical properties of Nitisol in Jimma zone, Southwestern Ethiopia. Inter. Res. J. Agr. Sci. Soi. Sci. 19: 394-401.

Ogbeibu, AE (2005). Biostatistics, A Practical Approach to Research and Data Handling. Mindex Publishing Company Limited, Benin City. Edo State. Nigeria. 264p.

Pluchon, N; Grundale, MJ; Nilsson, MC; Kardol, P; Wardle, A (2014). Stimulation of boreal tree seedling growth by wood charcoal effects of charcoal properties, seedling species and soil fertility. Fun. Ecol. 28: 766-775.

Roy, K; Nagasaka, S; Ishikawa, S (2012). Effects of charcoal-treated soils on plant growth and nutrient leaching. Envir. Inf. Sci. Acad. J. Coll. 26: 201206.

Sreeju, SN; Babu, MM; Mariappan, C; Selvamohan, T (2011). Effect of physical and chemical mutagens on biopolymer producing strains and RAPD analysis of mutated strains. Arch. Appl. Sci. Res. 3: 233-246.

Thi, M. V; Chulaka, P; Kasem, S; Kaewsorn, P (2013). Effects of bio-charcoal and organic fertilizer on the growth of mini chinese kale. Agri. Sci. J. 44: 648-656.

Zhang, Y; Idowu, OJ; Brewer, CE (2016). Using agricultural residue biochar to improve soil quality of desert soil. Agri. 6: 1-11. 